\title{
Chronic Blockade of Neurotensin Receptors Strongly Reduces Sensitized, but Not Acute, Behavioral Response to D-amphetamine
}

Fany Panayi, M.S., Erwan Dorso, M.S., Laura Lambás-Señas, Ph.D., Bernard Renaud, Ph.D., Hélène Scarna, Ph.D., and Anne Bérod, Ph.D.

This study investigated the effect of a chronic blockade of neurotensin (NT) receptors on the sensitized behavioral response to amphetamine using a nonpeptide NT receptor antagonist, SR 48692. Rats received four injections of D-amphetamine ( 0.5 or $1 \mathrm{mg} / \mathrm{kg}$, IP) every other day (day 1, 3,5 and 7) and were then challenged with the same dose of amphetamine after a 6-day withdrawal (day 14) to establish the presence of locomotor sensitization. Daily administration of SR $48692(1 \mathrm{mg} / \mathrm{kg}$, IP) throughout the amphetamine regimen (day 1 to day 14) almost completely blocked the sensitized locomotor response to amphetamine without affecting stereotyped behaviors (experiment 1). The decreased amphetamine-induced sensitization in chronically SR 48692-treated rats did not appear to result from an influence on basal locomotor activity, as chronic SR 48692 treatment did not modify the spontaneous locomotor activity developed in response to mild stresses (experiment 2). Moreover, we showed that chronic pretreatment with SR $48692(1 \mathrm{mg} / \mathrm{kg}, 14$ daily IP injections) had no effect on the locomotor activation induced by a single IP administration of amphetamine (experiment 3). These data suggest that a sustained blockade of NT receptors considerably reduces the sensitized behavioral response to amphetamine without altering the acute effect of this psychostimulant or the locomotor activation induced by a mild stress. This ability of SR 48692 to specifically reduce the behavioral sensitization to amphetamine suggests that NT receptor antagonists could have potential clinical utility in the treatment of some psychiatric disorders.

[Neuropsychopharmacology 26:64-74, 2002]

(C) 2001 American College of Neuropsychopharmacology.

Published by Elsevier Science Inc
KEY WORDS: Neurotensin receptor antagonist; Neurotensin; Amphetamine; Sensitization; Behavior; Locomotion.

Repeated intermittent administration of psychostimulants, such as amphetamine and cocaine, leads to a pro-

From the Laboratoire de Neuropharmacologie et Neurochimie, INSERM U512, Université Claude Bernard, Faculté de Pharmacie, 8 Avenue Rockefeller, 69373 Lyon Cedex 08, France.

Address correspondence to: Dr A. Bérod, INSERM U 512, Université Claude Bernard, Faculté de Pharmacie, 8 Avenue Rockefeller, 69373 Lyon Cedex 08, France. Tel.: +4-78-77-75-53, Fax: +4-78-7772-09, E-mail: aberod@rockefeller.univ-lyon1.fr

Received September 12, 2000; revised July 23, 2001; accepted August 14, 2001.

Online publication: 8/15/01 at www.acnp.org/citations/Npp 081501165 . gressive enhancement of their behavioral stimulant effects, as well as a long-lasting hyperreactivity in response to environmental or pharmacological challenges (Antelman et al. 1980; Kalivas and Stewart 1991). This phenomenon, termed behavioral sensitization, is considered as a useful animal model for drug-induced psychosis and drug craving in humans (Robinson and Becker 1986; Robinson and Berridge 1993; Lieberman et al. 1997; Laruelle 2000).

The mesoaccumbens dopaminergic (DA) system, which originates within the ventral tegmental area (VTA) and projects to the nucleus accumbens (NAC), plays an important role in the behavioral sensitization to psychostimulants. Thus, repeated injections of am- 
phetamine into the VTA produce sensitized locomotor responses to systemic injections of amphetamine, cocaine and morphine. In contrast, although amphetamine produces locomotor stimulation upon acute injection into the NAC, repeated intra-NAC injections do not lead to sensitization (Kalivas and Weber 1988; Vezina and Stewart 1990; Hooks et al. 1992; Cador et al. 1995). Other studies have established that the mechanisms leading to the induction of sensitization require the action of DA, somatodendritically released by amphetamine, on D1 receptors in the VTA whereas DA release in the NAC appears as the prime event for the expression of behavioral sensitization (Vezina 1993, 1996; Pierce and Kalivas 1997a).

However, recent studies support the view that the neural underpinnings of behavioral sensitization implicate additional limbic areas and neurotransmitters such as the medial prefrontal cortex (mPFC) and its glutamatergic components (Wolf 1998; Cador et al. 1999) or the ventral pallidum and its GABAergic components (Pierce and Kalivas 1997a). Likewise, several lines of evidence suggest that neurotensin (NT), a neuropeptide closely associated with DA systems, could play a role in stimulant-induced sensitization. Indeed, NT has been shown to co-exist with DA in a subset of mesencephalic neurons that project to the NAC and mPFC (Hökfelt et al. 1984; Kalivas and Miller 1984; Seroogy et al. 1987; Studler et al. 1988; Bayer et al. 1991) and to be coreleased with DA following psychostimulant administration (During et al. 1992; Hertel et al. 1996). Moreover, the injection of NT into the VTA produces psychostimulant-like behavioral and neurochemical activation effects such as increased locomotor activity and rearing (Kalivas et al. 1983; Cador et al. 1985) and enhanced extracellular levels of DA in the NAC (Kalivas and Duffy 1990; Laitinen et al. 1990; Sotty et al. 1998). Interestingly, repeated injection of NT into the VTA leads to a behavioral and neurochemical sensitization (Kalivas and Taylor 1985; Elliott and Nemeroff 1986; Kalivas and Duffy 1990). Finally, cross-sensitization between NT and psychostimulants has been observed. Indeed, repeated activation of NT receptors in rats sensitizes to the stimulant effect of amphetamine (Rompré 1997) and reciprocally, rats which develop enhanced locomotor response to the specific DA uptake inhibitor GBR 12783 are also sensitized to the stimulant motor effect of [D-Trp ${ }^{11}$ ] NT, a NT agonist (Boulay et al. 1996).

Recently, several studies using a selective NT receptor antagonist, SR 48692 (Gully et al. 1993) provided evidence for the involvement of endogenous NT in the behavioral activating effects of cocaine (Horger et al. 1994; Betancur et al. 1998) and amphetamine (Rompré and Perron 2000). These studies however suggest that SR 48692 may differentially alter psychostimulant behavioral effects according to its administration schedule. Chronic preexposure to SR 48692 delayed the develop- ment of cocaine sensitization in rats, whereas its administration only prior to each cocaine or amphetamine injection respectively did not affect (Horger et al. 1994) or only slightly reduced behavioral sensitization (Rompré and Perron 2000). The purpose of the present study was thus to examine whether chronic blockade of NT receptors with SR 48692 could lead to a lasting attenuation of the sensitization phenomenon to amphetamine.

\section{MATERIALS AND METHODS}

\section{Animals}

Male Sprague-Dawley (OFA strain) rats (Iffa-Credo, France) weighing 200 to $220 \mathrm{~g}$ were housed four per cage in a temperature $\left(22^{\circ} \mathrm{C}\right)$ controlled environment under a 12:12-h light/dark cycle (light from 6:00 A.M. to 6:00 P.M.), with ad libitum access to food and water. Rats were allowed to habituate one week to the animal room prior to their use. The experiments were performed between 11:00 A.M. and 5:00 P.M. All procedures were done in accordance with the European Community Council Directives for the care and the use of laboratory animals.

\section{Drugs}

D-amphetamine sulfate obtained from Sigma was dissolved in a saline solution $(\mathrm{NaCl} 0.9 \%)$ and injected IP $(1 \mathrm{ml} / \mathrm{kg})$ at the dose of 0.5 or $1 \mathrm{mg} / \mathrm{kg}$. The NT antagonist, SR 48692 (Sanofi-Synthélabo, Montpellier, France) was suspended with Tween 80 in saline, and injected IP $(1 \mathrm{ml} / \mathrm{kg})$ at the dose of 0.1 or $1 \mathrm{mg} / \mathrm{kg}$.

Control rats were injected with saline and vehicle (saline with $1 \%$ Tween 80 ).

\section{Behavioral Measurements}

Motor activity was monitored in Plexiglas cages (area: $26 \times 41 \mathrm{~cm}$; height: $20 \mathrm{~cm}$ ) equipped with an array of four parallel horizontal infra-red beams (two at the front and two at the back) positioned $4 \mathrm{~cm}$ above the floor to measure horizontal activity. The activity cages were linked to a computer, which recorded photocell beam breaks. Locomotion was estimated by determination of successive breaks at the front and at the back and vice versa (crossovers). The number of crossovers was continuously recorded and cumulated over 10-min intervals.

To assess the qualitative features of the behavioral response to $1 \mathrm{mg} / \mathrm{kg}$ amphetamine, animals were rated for $30 \mathrm{~s}$ beginning $4 \mathrm{~min}$ after injection and at successive $10 \mathrm{~min}$ intervals for up to $2 \mathrm{~h}$. Earphones provided a tone signal which indicated the beginning and ending of the rating period. An investigator unaware of the drug treatment measured the time the animal engaged in focused stereotypies (repetitive head and limb move- 
ments, sniffing or oral stereotypies). The chronometer was started after the animal exhibited a stereotyped behavior for 2 to $3 \mathrm{~s}$ in the absence of locomotor activity. Data are presented as the percentage of time the animal displayed the specific stereotyped response during the observation period.

\section{Experimental Design}

One week before experiments, rats were first exposed to the activity cages without any injection and their locomotor response to novelty recorded. Animals were then homogeneously assigned to different experimental groups depending on their responsiveness to novelty so that mean spontaneous locomotion for all the groups did not differ significantly. Such distribution minimizes differences between the experimental groups in their response to amphetamine since it has been previously shown that the locomotor response to novelty is a good predictor of the motor effects of psychostimulants (Piazza et al. 1989; Hooks et al. 1991).

Experiment 1: Effect of a Daily Treatment with SR 48692 on Behavioral Sensitization to Amphetamine $(0.5$ and $1 \mathrm{mg} / \mathrm{kg}$ ). Rats were sensitized by four administrations of amphetamine ( 0.5 or $1 \mathrm{mg} / \mathrm{kg}$ ), one injection every other day (days 1, 3, 5 and 7) and then challenged with the same dose of amphetamine after six days of drug withdrawal (day 14). These rats also received SR 48692 ( 0.1 or $1 \mathrm{mg} / \mathrm{kg}$ ) or vehicle once daily from day 1 to day 14. For each experiment, control rats were injected with both saline (five injections on days 1, 3, 5, 7 and 14) and vehicle (once daily for 14 days). So, three treatment groups were formed: SR $48692+$ Amph $(\mathrm{n}=$ 16 per experiment), Vehicle + Amph $(n=16$ per experiment) and Vehicle + Saline $(n=8$ per experiment).

Motor activity was recorded on days 1, 7 and 14. After a 2-h habituation period in the activity cages, animals were injected with SR 48692 or vehicle followed 30 min later by the administration of amphetamine or saline. Following injections, each rat was immediately returned to its activity cage. Locomotor activity and stereotypies were measured during $2 \mathrm{~h}$ after amphetamine or saline injection. On days 3 and 5, drugs were administered in the home cage.

To examine whether chronic blockade of NT receptors could modify on a long-term basis the sensitized locomotor response to $1 \mathrm{mg} / \mathrm{kg}$ amphetamine, chronic treatment with SR $48692(1 \mathrm{mg} / \mathrm{kg})$ was prolonged from day 14 to day 21 and a second challenge of the same dose of psychostimulant was administered on day 21. In this case, motor activity was recorded as previously described but only during one hour because rat brains were removed for an independent histological study.
Experiment 2: Effect of a Daily Treatment with SR 48692 on Basal Locomotor Activity. To assess the effect of repeated exposure to SR $48692(1 \mathrm{mg} / \mathrm{kg})$ on basal locomotor activity, rats received fourteen IP daily injections of SR $48692(n=8)$ or vehicle $(n=8)$. On day 14, the animals were tested for novelty- and IP injection-induced locomotor activation. Activity counts were recorded for $2 \mathrm{~h}$ following the placement of rats in the activity test cage (novel environment), then for 30 min following the last SR 48692 or vehicle injection and for an additional $2 \mathrm{~h}$ following a saline challenge.

Experiment 3: Effect of a Daily Treatment with SR 48692 on Locomotor Response to Acute Amphetamine. Rats were daily preexposed to SR 48692 (1 $\mathrm{mg} / \mathrm{kg}$ ) or vehicle for 14 days. The animals were tested the fourteenth day as described in Experiment 1. After a 2-h habituation period in the activity cages, animals received the last SR 48692 or vehicle injection followed 30 min later by one administration of amphetamine or saline, and locomotor activity was monitored for $2 \mathrm{~h}$. Three treatment groups were formed: SR $48692+$ Amph $(n=16)$, Vehicle + Amph $(n=16)$ and Vehicle + Saline $(\mathrm{n}=8)$.

\section{Statistical Analysis}

Locomotor activity data (crossovers) were subjected to 2-way analysis of variance (ANOVA) with one betweensubject factor (Treatment) and one within-subject factor (Time). In addition, whenever main factor effects were found, post hoc comparisons were made using the Student-Newman-Keuls test. In cases in which only two groups were compared a Student's $t$-test was used: differences between experimental groups were assessed using an unpaired test and differences between days using a paired test.

\section{RESULTS}

Experiment 1: Effect of a daily treatment with SR 48692 on behavioral sensitization to amphetamine

Figure 1 shows the effects of SR $48692(1 \mathrm{mg} / \mathrm{kg})$ on locomotor activity induced by amphetamine administration at the dose of $0.5 \mathrm{mg} / \mathrm{kg}$ (top panels) or $1 \mathrm{mg} / \mathrm{kg}$ (bottom panels). The time course of locomotor responses as well as total crossovers made over the $2 \mathrm{~h}$ following the first amphetamine injection (day 1 ) or the amphetamine challenge performed after a 6-day withdrawal (day 14) are respectively shown in the left and the right panels.

AMPHETAMINE 0.5 MG/KG. The initial injection of amphetamine $0.5 \mathrm{mg} / \mathrm{kg}$ (day 1) produced a small, nonsignificant increase in locomotion indicating that this is a threshold dose for the induction of locomotor activity. 

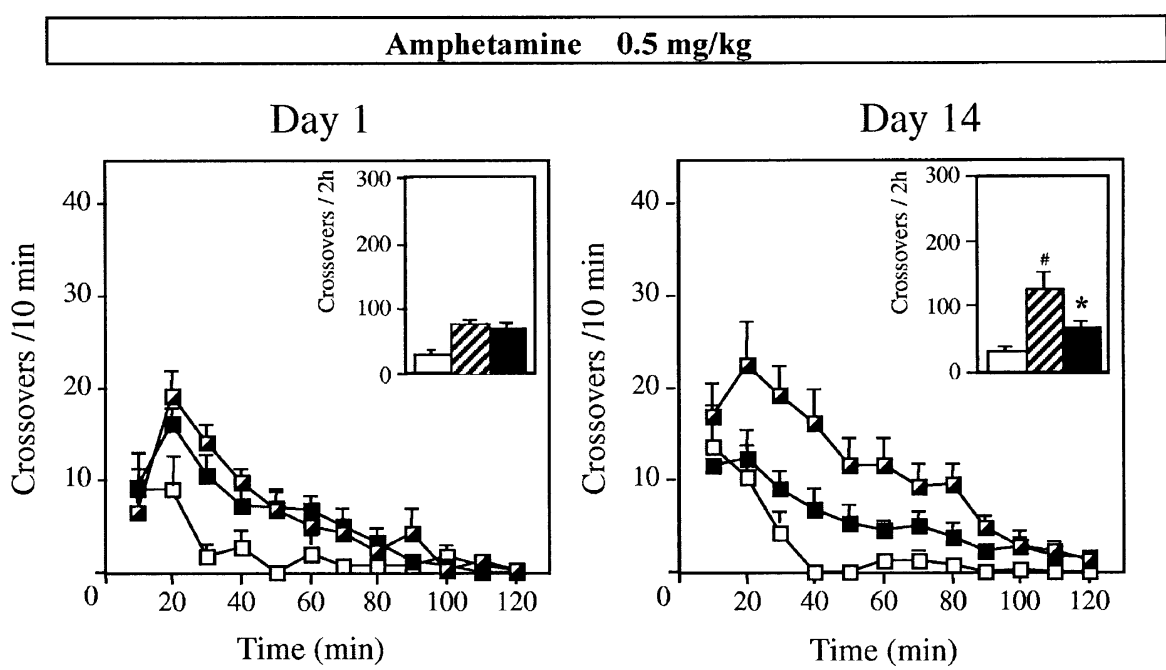

Vehicle + Saline $(\mathrm{n}=8)$

Vehicle + Amph $(\mathrm{n}=16)$

- SR $48692+\operatorname{Amph}(\mathrm{n}=16)$



Day 14

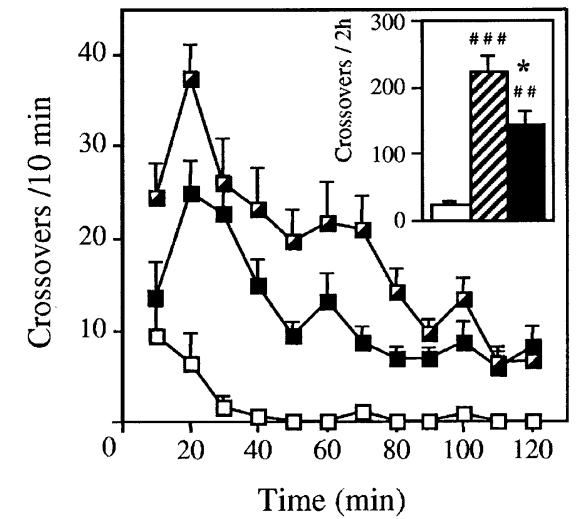

Figure 1. Experiment 1. Effect of SR $48692(1 \mathrm{mg} / \mathrm{kg}$, IP) on the locomotor responses to amphetamine at the dose of $0.5 \mathrm{mg} / \mathrm{kg}$, IP (top panels) or $1 \mathrm{mg} / \mathrm{kg}$, IP (bottom panels). The data represent the mean (+SEM) locomotor activity scores (crossovers), summed across 10-min intervals, for the $120 \mathrm{~min}$ following the first (Day 1, left panels) and the last (Day 14, right panels) amphetamine injections in animals daily treated with vehicle or SR 48692 for 14 days. The insets give the mean $(+\mathrm{SEM})$ total crossovers scored over the 2-h post-injection period. Repeated amphetamine administration induced an increase in locomotion between days 1 and $14(p<.01$ for $0.5 \mathrm{mg} / \mathrm{kg}$ and $p<.001$ for 1 $\mathrm{mg} / \mathrm{kg}$ ), indicating the appearance of behavioral sensitization in Vehicle + Amph groups. One injection of SR 48692 performed $30 \mathrm{~min}$ before the first amphetamine administration did not affect the locomotion elicited by the psychostimulant (day 1), but repeated injections of SR 48692 decreased the sensitized response to amphetamine (day 14) (ANOVA, $p<.05$ ). ${ }^{*} p<.05$ compared with Vehicle + Amph group, $\# p<.05, \# \#<.01$, \#\#\# $<.001$ compared with Vehicle + Saline group, (Newman-Keuls post hoc test).
This activity was not modified by one preinjection of SR $48692\left(\mathrm{~F}_{2,35}=2.40\right.$, n.s.) (Figure 1, upper left panel). Likewise, on day 7 , amphetamine slightly raised locomotion, and treatment with SR 48692 had no significant effect on this locomotor response [crossovers/2h: $35 \pm$ 9 in Vehicle + Saline group; $94 \pm 17$ in Vehicle + Amph group and $67 \pm 11$ in SR $48692+$ Amph group; treatment, $\mathrm{F}_{2,35}=2.72$, n.s.].

In contrast, challenge administration of $0.5 \mathrm{mg} / \mathrm{kg}$ amphetamine on day 14 significantly increased locomotion in Vehicle + Amph group (Day 1: $74 \pm 11$ crossovers/2h versus Day 14: $128 \pm 25 ; p<.01)$. This increase between days 1 and 14 represents the expression of amphetamine-induced locomotor sensitization. Daily injection of SR 48692 from day 1 to day 14 prevented this sensitization phenomenon since the locomotor response to amphetamine of SR $48692+$ Amph group remained unchanged between days 1 and 14 (Day 1: $68 \pm 12$ crossovers/2h ; Day 14: $68 \pm 13$ ). On day 14 (Figure 1, right panels) the overall ANOVA indicated a significant main treatment effect $\left(\mathrm{F}_{2,35}=4.58\right.$, $p<.05)$ and post hoc analyses revealed that Vehicle + Amph group showed a significantly greater locomotor response compared with SR $48692+$ Amph $(p<.05)$ and Vehicle + Saline groups $(p<.05)$.

AMPHETAMINE 1 MG/KG. This experiment was performed to examine whether SR 48692 treatment could affect the locomotor response to a higher dose of amphetamine. On day 1 (Figure 1, lower left panel), the first injection of amphetamine $1 \mathrm{mg} / \mathrm{kg}$ induced a marked elevation in locomotion when compared with saline-treated rats and again acute treatment with SR 48692 did not significantly modify the amphetamine-induced locomotion. The ANOVA indicated a main treatment effect $\left(\mathrm{F}_{2,37}=\right.$ 
12.29, $p<.0001)$. Post hoc multiple comparisons revealed that Vehicle + Amph and SR $48692+$ Amph groups were significantly different from the Vehicle + Saline group $(p<.0001$ and $p<.01$, respectively). Again, on day 7, amphetamine significantly increased locomotor activity but SR 48692 had no effect on this behavioral response [crossovers/2h: $11 \pm 4$ in Vehicle + Saline group; $128 \pm 21$ in Vehicle + Amph group; $99 \pm 20$ in SR $48692+$ Amph group]. The ANOVA indicated a main treatment effect $\left(\mathrm{F}_{2,37}=6.3, p<.01\right)$ and post hoc analysis revealed that Vehicle + Amph and SR 48692 + Amph groups were significantly different from the Vehicle + Saline group $(p<.01)$.

Challenge administration of $1 \mathrm{mg} / \mathrm{kg}$ amphetamine on day 14 elicited a pronounced behavioral sensitization in the Vehicle + Amph group (Day 1: $133 \pm 17$ crossovers/2h versus Day 14: $224 \pm 26 ; p<.001)$. As previously observed with the dose of amphetamine 0.5 $\mathrm{mg} / \mathrm{kg}$, the sensitized locomotor response was markedly reduced in chronically SR 48692-treated animals. On day 14 (Figure 1, right panel) the overall ANOVA indicated a significant main treatment effect $\left(\mathrm{F}_{2,37}=13.36, p<.0001\right)$ and post hoc analysis revealed that each group was significantly different from the two others (Vehicle + Saline/Vehicle + Amph, $p<.0001$; Vehicle + Saline/SR $48692+$ Amph, $p<.01$; Vehicle + Amph/SR $48692+$ Amph, $p<.05$ ).

In order to ascertain that the decrease in overall locomotor activity observed in SR $48692+$ Amph rats was not due to an enhanced level of stereotyped behaviors, we measured the time the animals spent engaged in focused stereotypies. As shown in Figure 2, no difference was observed for stereotypies between vehicle- and SR 48692-treated rats challenged with amphetamine.

A second amphetamine challenge $(1 \mathrm{mg} / \mathrm{kg})$ was performed on day 21 after continuing daily SR 48692 treatment, and locomotor activity was recorded during one hour following the amphetamine injection. To provide an overview of the SR 48692 effects on behavioral sensitization, all the data of experiment 1 are shown in Figure 3 as cumulative crossovers during the first hour of monitoring after the amphetamine challenge. The behavioral sensitization was still observed on day 21 in Vehicle + Amph group and the SR 48692 significantly decreased the sensitized response to amphetamine in SR 48692 + Amph group with the same order of magnitude as on day 14 (Figure 3 ). This suggests that a chronic SR 48692 treatment can maintain on a longterm basis a reduced amphetamine-sensitization.

A last experiment showed that blockade of NT receptors with a lower dose of SR $48692(0.1 \mathrm{mg} / \mathrm{kg})$ neither affected the acute locomotor response to amphetamine (day 1) nor the behavioral sensitization (day 14) to this psychostimulant (Table 1).

\section{Experiment 2: Effect of a Daily Treatment with SR 48692 on Basal Locomotor Activity}

As can be seen in Figure 4, after the animals were introduced in the activity cages, they developed spontaneous locomotor activity, corresponding to the exploration of the novel environment during the first $40 \mathrm{~min}$. Chronic treatment with SR $48692(1 \mathrm{mg} / \mathrm{kg})$ neither altered the

Day 14

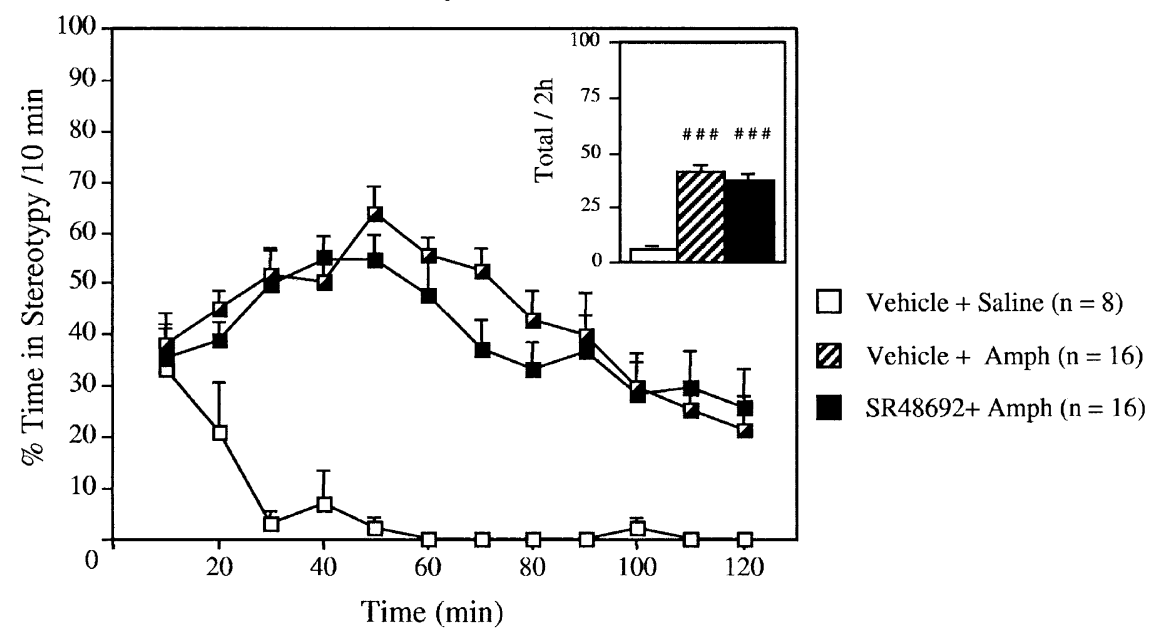

Figure 2. Experiment 1. Effect of a daily treatment with SR $48692(1 \mathrm{mg} / \mathrm{kg}, \mathrm{IP})$ during 14 days on the stereotyped behaviors observed in rat sensitized by repeated administration of amphetamine $1 \mathrm{mg} / \mathrm{kg}$, IP. Data are shown as means + SEM and represent the percentage of time animals spent engaged in stereotyped behaviors (repetitive head and limb movements or oral behaviors). Bar graphs represent the stereotyped response scored over a 2-h post-injection period. Repeated SR 48692 administration did not affect the stereotyped response to the $1 \mathrm{mg} / \mathrm{kg}$ amphetamine challenge (day 14 ). \#\#\# $p$.001 compared with Vehicle + Saline group, using ANOVA followed by Newman-Keuls test. 
behavioral response to novelty $\left(\mathrm{F}_{1,14}=0.10\right.$, n.s. $)$ nor the slight increase of locomotion induced by vehicle $\left(\mathrm{F}_{1,14}=\right.$ 1.21 , n.s. $)$ and saline $\left(\mathrm{F}_{1,14}=0.06\right.$, n.s.) injections, suggesting that the effect of the NT receptor antagonist on the sensitized locomotor response to amphetamine does not depend on a general impairment of motor behavior.

\section{Experiment 3: Effect of a Daily Treatment with SR 48692 on Locomotor Response to Acute Amphetamine}

To check whether chronic blockade of NT receptors could attenuate the locomotor response to an acute amphetamine exposure, SR $48692(1 \mathrm{mg} / \mathrm{kg})$ was given once daily for 14 days before a single injection of amphetamine (performed $30 \mathrm{~min}$ after the last SR 48692 administration). Figure 5 represents the locomotor activity during $2 \mathrm{~h}$ of recording of the three pretreated groups following the injection of a single dose of amphetamine $(1 \mathrm{mg} / \mathrm{kg})$ or saline. The same amphetamine-induced increase in locomotor activity was observed in the vehicleand SR 48692-pretreated groups compared with the control group $\left(\mathrm{F}_{2,37}=6.65, p<.01\right)$. Post hoc two-by-two comparisons indicated that there was a significant difference between the amphetamine treated groups and the saline treated group $(p<.01)$. This suggests that chronic treatment with SR 48692 does not modulate the acute locomotor response to amphetamine.

\section{DISCUSSION}

Our results demonstrate that chronic blockade of NT receptors strongly attenuates the sensitized locomotor response to amphetamine. Indeed, daily injection of the
NT receptor antagonist, SR 48692, throughout the amphetamine regimen almost completely blocks the sensitized locomotor response to this drug, an effect that persists at least as long as the SR 48692 administration is maintained. Importantly, this decrease in behavioral response occurs without any change in the time spent in stereotyped behaviors. These data argue against the possibility that SR 48692 could reduce the locomotor sensitization simply by a qualitative shift in behavior from hyperlocomotion to focused stereotypies. It is worth noting that the effects of SR 48692 on sensitized locomotor response to amphetamine are produced by doses somewhat higher than those which acutely antagonize the effects of exogenous NT in mice and rats (Poncelet et al. 1994; Steinberg et al. 1995), suggesting that such behavioral changes require a higher level of NT receptor blockade. Interestingly, repeated administration of SR 48692 does not impair rat locomotor activity in response to a mild stress (novelty or needle jab) and to a single injection of amphetamine indicating a specific action of this treatment on the enhanced locomotor response of animals sensitized to amphetamine.

These results are in line with previous studies supporting the hypothesis that endogenous NT could play a permissive role in the behavioral response to psychostimulants (Horger et al. 1994; Betancur et al. 1998; Rompré and Perron 2000) but, more importantly, they show that a sustained blockade of NT receptors can specifically restrain, on a long-term basis, the behavioral sensitization. This raises the question whether SR 48692 acts all along the process or specifically during the initiation or during the expression phase of this phenomenon. Although Rompré and Perron (2000) recently suggested that endogenous NT could play a role

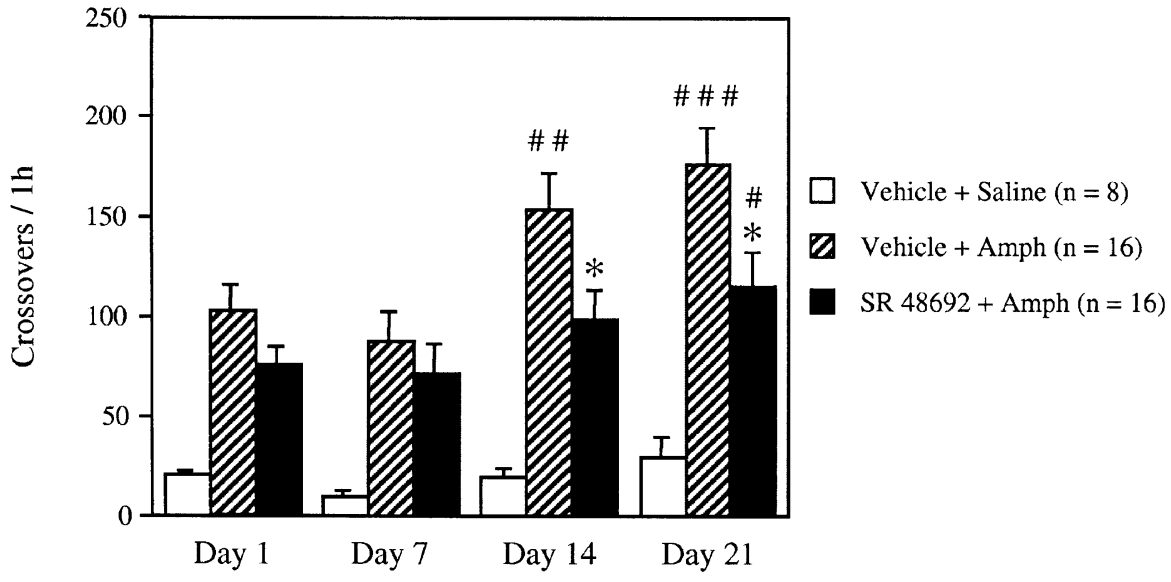

Figure 3. Experiment 1. Effect of SR $48692(1 \mathrm{mg} / \mathrm{kg}, \mathrm{IP})$ on the locomotor response to amphetamine $(1 \mathrm{mg} / \mathrm{kg}, \mathrm{IP}) \mathrm{on}$ each of the four test days (days 1, 7, 14 and 21). Data are derived from the same groups of rats as those in Figure 1. In this case, they represent mean (+ SEM) of cumulative crossovers only during 60 min of monitoring after amphetamine injections, to compare days 1, 7 and 14 with day 21. In vehicle + Amph group, behavioral sensitization was observed on days 14 and 21 . SR 48692 significantly reduced this behavioral sensitization on days 14 and 21. ${ }^{*} p<.05$ compared with Vehicle + Amph group; ${ }^{*}<.05$, \#\# $p$.01, \#\# $p<.001$ compared with day 1 of the same experimental group. 
Table 1. Experiment 1. Effect of SR $48692(0.1 \mathrm{mg} / \mathrm{kg}$, IP) on the Behavioral Sensitization to Amphetamine $(1 \mathrm{mg} / \mathrm{kg}$, IP)

\begin{tabular}{lccc}
\hline Experimental groups & Day $\mathbf{1}$ & Day 7 & Day 14 \\
\hline Vehicle + Saline & $26 \pm 6$ & $22 \pm 3$ & $39 \pm 8$ \\
Vehicle + Amph & $107 \pm 11$ & $166 \pm 21$ & $217 \pm 20$ \\
SR 48692 + Amph & $114 \pm 19$ & $199 \pm 39$ & $217 \pm 48$ \\
\hline
\end{tabular}

Data are mean $( \pm$ SEM) total crossovers $/ 2 \mathrm{~h}$. In Vehicle + Amph and SR 48692 + Amph groups, the behavioral sensitization phenomenon is expressed by a similar increase in locomotor response to amphetamine across days (ANOVA, $\mathrm{p}<0.001$ ). Thus SR 48692, at $0.1 \mathrm{mg} / \mathrm{kg}$, neither affected the acute locomotor response to amphetamine (day 1 ) nor the behavioral sensitization (day 14) to this psychostimulant.

in the initiation of amphetamine sensitization, their study requires to be extended using chronic treatments and/or higher doses of SR 48692.

The mechanisms responsible for the effect of chronic SR 48692 on behavioral sensitization are currently unknown. However, according to the pharmacological properties of NT receptors and their localization in the brain, several potential targets for SR 48692 can be proposed. Two types of functionally relevant NT receptors (for review see Vincent et al. 1999) have been identified and cloned from rodent and human brains, and shown to belong to the family of seven transmembrane domains G-protein-coupled receptors (Tanaka et al. 1990; Vita et al. 1993; Chalon et al. 1996; Mazella et al. 1996). The subtype 1 (NT1) shows a high affinity for NT $(\mathrm{Kd} \simeq 0.1-0.3 \mathrm{nM})$ whereas the subtype 2 (NT2) shows a lower affinity for the peptide $(\mathrm{Kd} \simeq 2-4 \mathrm{nM})$ and is sensitive to levocabastine, a histamine antagonist. The third NT receptor (NT3) which has only recently been cloned is a single transmembrane domain receptor and could be involved in intracellular trafficking (Mazella et al. 1998). In vitro binding studies from various species brain tissue revealed that SR 48692 can bind to both NT1 and NT2, but with a much lower affinity for the latter (Gully et al. 1993) and displays no affinity for NT3 (Mazella et al. 1998). Acute systemic administration of SR 48692 reverses the turning behavior induced by intrastriatal injection of NT in mice (Poncelet et al. 1994) and controlateral circling induced by intra-VTA injection of NT in rats (Steinberg et al. 1994). However, SR 48692, even over a wide dose range $(0.5-4 \mathrm{mg} / \mathrm{kg})$, fails to antagonize NT-induced analgesia in mice and rats, an effect mediated by NT2 receptors (Dubuc et al. 1994, 1999). Thus, in the absence of NT2 selective antagonists and in view of the pharmacological profile of SR 48692, it can be tentatively suggested that the counteractive effect of SR 48692 on behavioral sensitization to amphetamine likely involves blockade of NT1 receptors.

NT1 receptor and its endogenous ligand are present in several key structures of the neuronal circuitry involved in the behavioral response to psychostimulants such as the VTA, the NAC, the ventral pallidum, and the mPFC (Jennes et al. 1982; Zahm and Heimer 1988; Febvret et al. 1991; Woulfe and Beaudet 1992; Nicot et al. 1994; Alexander and Leeman 1998), where NT exerts different effects on behavior and DA release, depending on its injection site. Indeed, NT microinjection into the VTA has been reported to increase locomotion as well as DA release in the NAC (see Introduction). Conversely, NT microinjection into the NAC decreases the behavioral responses induced by DA agonists, such as amphetamine, cocaine or apomorphine (Ervin et al. 1981; Ford and Marsden 1990; Robledo et al. 1993). Both of these NT-induced behavioral effects were reversed by systemic acute injection of SR 48692 (Steinberg et al. 1994) suggesting that NT receptors in the VTA and the NAC could be possible brain sites of SR 48692 action.

Given the importance of the DA mesolimbic system in the mediation of behavioral sensitization and the numerous interactions between DA and NT systems, we can postulate that the SR 48692 effect shown in our study is related to its ability to affect several aspects of DA neurons functioning. We previously reported that SR 48692 administration for two weeks, at the dose of $1 \mathrm{mg} / \mathrm{kg}$, produced a drastic reduction in the basal extracellular levels of DA in the NAC (Azzi et al. 1998). Moreover, repeated systemic injection of SR 48692 was shown to induce a time-dependent decrease in the number of spontaneously active DA cells in the VTA (Santucci et al.

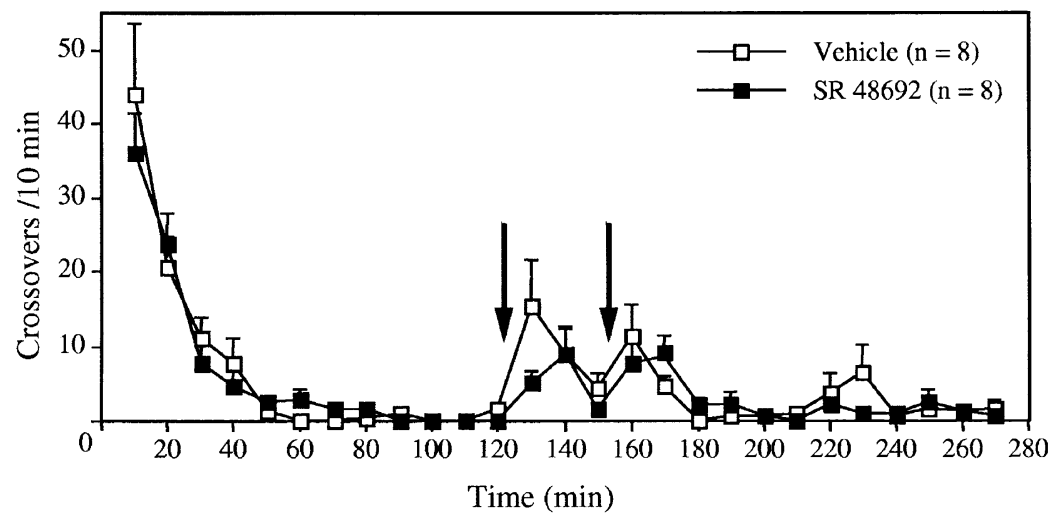

Figure 4. Experiment 2. Effect of a daily treatment with SR $48692(1 \mathrm{mg} / \mathrm{kg}$, IP) during 14 days on basal locomotor activity. Values are expressed as means + SEM and represent the time course of locomotion following i) the placement of rats in a novel environment (0-120 min), ii) the last IP injection of vehicle or SR 48692 (first arrow, 120$150 \mathrm{~min}$ ) and iii) an IP injection of saline (second arrow, 150-270 min). Repeated SR 48692 pretreatment did not influence locomotor response to these mild stresses. 


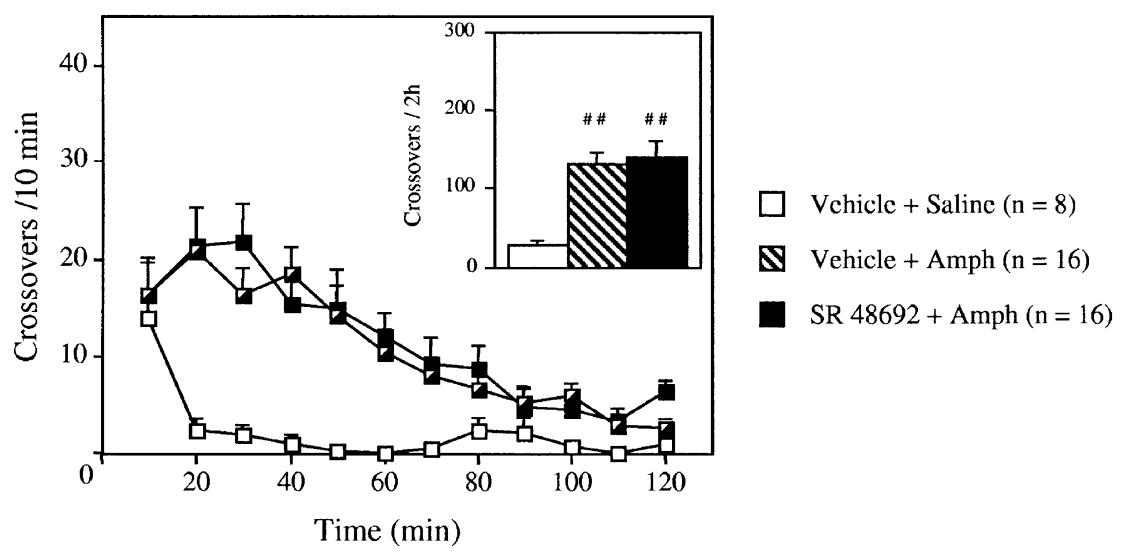

Figure 5. Experiment 3. Effect of a daily treatment with SR 48692 (1 mg/kg, IP) during 14 days on locomotor response to acute amphetamine $(1 \mathrm{mg} / \mathrm{kg}, \mathrm{IP})$. Values are expressed as means + SEM and represent the time course of locomotion in response to a single amphetamine injection. Bar graphs in the inset represent the locomotor response cumulated over a 2-h post-injection period. Repeated SR 48692 administration did not modify the locomotor activity induced by one amphetamine injection. ${ }^{\#} p<.01$ compared with Vehicle + Saline group, using ANOVA followed by Newman-Keuls test.

1997). These effects of SR 48692 on DA systems were not found after acute administration (Steinberg et al. 1994) and appeared only after prolonged treatment (Santucci et al. 1997; Azzi et al. 1998). Together, these data indicate that SR 48692 per se, when administered chronically, attenuates the DA mesolimbic activity, an effect that may somehow counteract those produced by repeated administration of psychostimulants. This hypothesis explaining attenuation of amphetamine-sensitization by NT antagonist remains to be tested and an important issue to examine is the effect of chronic NT antagonists on amphetamine-induced DA changes in the NAC.

Finally, recent studies emphasized the importance of the role played by calcium and calcium-mediated second messengers systems specifically in the behavioral and neurochemical sensitization to psychostimulants. Microinjection of calcium channel antagonists into the NAC dose-dependently impaired behavioral sensitization to cocaine without altering the acute locomotor response to this psychostimulant (Pierce et al. 1998). Similarly, other experiments revealed that the sensitized DA release in the NAC induced by amphetamine is calcium-dependent and can be attenuated by a selective calmodulin-dependent protein kinase II inhibitor, whereas DA release induced by a single dose of amphetamine is calcium-independent (Carboni et al. 1989; Warburton et al. 1996; Pierce and Kalivas 1997b; Kantor et al. 1999). Thus, one may hypothesize that blockade of NT receptors alters the behavioral sensitized response to amphetamine by acting on the calcium-dependent portion of the DA response to amphetamine. This would be consistent with the observation that NT robustly increases intracellular calcium concentrations in various cell types (for review see Vincent 1995), and in particular in DA neurons from the ventral mesencephalon (Legault and Trudeau 2000).
In conclusion, we showed that a sustained blockade of NT receptors specifically reduces the sensitized behavioral effect of amphetamine, suggesting that endogenous NT participates in behavioral events produced by repeated amphetamine exposure. The same treatment did not affect the locomotor response to a single injection of amphetamine or a mild stress. These results support the proposal that peptides may play an important role when the nervous system is highly challenged by drugs or afflicted by diseases and, that peptide antagonists, in acting only on disturbed systems with increased peptide release, should direct to the development of new therapeutic strategies (Hökfelt et al. 2000). Indeed, the behavioral sensitization to amphetamine is not only seen in rodents, but also in humans where it can lead to psychotic episodes (Lieberman et al. 1997). The ability of SR 48692 to lessen the behavioral sensitization to amphetamine suggests that NT receptor antagonists could have potential clinical utility in the treatment of some psychiatric disorders.

\section{ACKNOWLEDGMENTS}

We thank Drs. Philippe Soubrié and Régis Steinberg for helpful discussions and Dr. Danielle Gully (Sanofi-Synthélabo) for providing SR 48692. This work was supported by INSERM and Université Claude Bernard-Lyon (Lyon, France).

\section{REFERENCES}

Alexander MJ, Leeman SE (1998): Widespread expression in adult rat forebrain of $\mathrm{mRNA}$ encoding high-affinity neurotensin receptor. J Comp Neurol 402:475-500

Antelman SM, Eichler AJ, Black CA, Kocan D (1980): Interchangeability of stress and amphetamine in sensitization. Science 207:329-331 
Azzi M, Betancur C, Sillaber I, Spanagel R, Rostène W, Bérod A (1998): Repeated administration of the neurotensin receptor antagonist SR 48692 differentially regulates mesocortical and mesolimbic dopaminergic systems. J Neurochem 71:1158-1167

Bayer VE, Towle AC, Pickel VM (1991): Ultrastructural localization of neurotensin-like immunoreactivity within dense core vesicles in perikarya, but not terminals, colocalizing tyrosine hydroxylase in the rat ventral tegmental area. J Comp Neurol 311:179-196

Betancur C, Cabrera R, De Kloet ER, Pélaprat D, Rostène W (1998): Role of endogenous neurotensin in the behavioral and neuroendocrine effects of cocaine. Neuropsychopharmacology 19:322-332

Boulay D, Duterte-Boucher D, Nouel D, Costentin J (1996): Locomotor sensitization to [D-Trp ${ }^{11}$ ] neurotensin after repeated injections of the dopamine uptake inhibitor GBR 12783 in rats. Neurosci Lett 208:5-8

Cador M, Kelley AE, Le Moal M, Stinus L (1985): Behavioral analysis of the effect of neurotensin injected into the ventral mesencephalon on the investigatory and spontaneous motor behavior in the rat. Psychopharmacology 85:187-196

Cador M, Bjijou Y, Stinus L (1995): Evidence for a complete independence of the neurobiological substrates for the induction and expression of behavioral sensitization to amphetamine. Neuroscience 65:385-395

Cador M, Bjijou Y, Cailhol S, Stinus L (1999): D-amphetamine-induced behavioral sensitization: implication of a glutamatergic medial prefrontal cortex-ventral tegmental area innervation. Neuroscience 94:705-721

Carboni E, Imperato A, Perezzani L, Di Chiara G (1989): Amphetamine, cocaine, phencyclidine and nomifensine increase extracellular dopamine concentrations preferentially in the nucleus accumbens of freely moving rats. Neuroscience 28:653-661

Chalon P, Vita N, Kaghad M, Guillemot M, Bonnin J, Delpech B, Le Fur G, Ferrara P, Caput D (1996): Molecular cloning of a levocabastine-sensitive neurotensin binding site. FEBS Lett 386:91-94

Dubuc I, Costentin J, Terranova JP, Barnouin MC, Soubrié P, Le Fur G, Rostène W, Kitabgi P (1994): The nonpeptide neurotensin antagonist, SR 48692, used as a tool to reveal putative neurotensin receptor subtypes. $\mathrm{Br} \mathrm{J}$ Pharmacol 112:352-354

Dubuc I, Sarret P, Labbé-Jullié C, Botto JM, Honore E, Bourdel E, Martinez J, Costentin J, Vincent JP, Kitabgi P, Mazella J (1999): Identification of the receptor subtype involved in the analgesic effect of neurotensin. J Neurosci 19:503-510

During MJ, Bean AJ, Roth RH (1992): Effects of CNS stimulants on the in vivo release of the colocalized transmitters, dopamine and neurotensin, from prefrontal cortex. Neurosci Lett 140:129-133

Elliott PJ, Nemeroff CB (1986): Repeated neurotensin administration in the ventral tegmental area: effects on baseline and d-amphetamine-induced locomotor activity. Neurosci Lett 68:239-244

Ervin GN, Birkemo LS, Nemeroff CB, Prange AJ Jr (1981): Neurotensin blocks certain amphetamine-induced behaviors. Nature 291:73-76

Febvret A, Berger B, Gaspar P, Verney C (1991): Further indi- cation that distinct dopaminergic subsets project to the rat cerebral cortex: lack of colocalization with neurotensin in the superficial dopaminergic fields of the anterior cingulate, motor, retrosplenial and visual cortices. Brain Res 547:37-52

Ford AP, Marsden CA (1990): In vivo neurochemical and behavioural effects of intracerebrally administered neurotensin and D-Trp11-neurotensin on mesolimbic and nigrostriatal dopaminergic function in the rat. Brain Res 534:243-250.

Gully D, Canton M, Boigegrain R, Jeanjean F, Molimard JC, Poncelet M, Gueudet C, Heaulme M, Leyris R, Brouard A, Pélaprat D, Labbé-Jullié C, Mazella J, Soubrié P, Maffrand JP, Rostène W, Kitabgi P, Le Fur G (1993): Biochemical and pharmacological profile of a potent and selective nonpeptide antagonist of the neurotensin receptor. Proc Natl Acad Sci USA 90:65-69

Hertel P, Mathé JM, Nomikos GG, Iurlo M, Mathé AA, Svensson TH (1996): Effects of D-amphetamine and phencyclidine on behavior and extracellular concentrations of neurotensin and dopamine in the ventral striatum and the medial prefrontal cortex of the rat. Behav Brain Res 72:103-114

Hökfelt T, Everitt BJ, Theodorsson-Norheim E, Goldstein M (1984): Occurrence of neurotensin-like immunoreactivity in subpopulations of hypothalamic, mesencephalic, and medullary catecholamine neurons. J Comp Neurol 222:543-559

Hökfelt T, Broberger C, Xu Z-QD, Sergeyev V, Ubink R, Diez M (2000): Neuropeptides-an overview. Neuropharmacology 39:1337-1356.

Hooks MS, Jones GH, Neill DB, Justice JB Jr (1991): Individual differences in amphetamine sensitization: dose-dependent effects. Pharmacol Biochem Behav 41:203-210

Hooks MS, Jones GH, Liem BJ, Justice JB Jr (1992): Sensitization and individual differences to IP amphetamine, cocaine, or caffeine following repeated intra-cranial amphetamine infusions. Ann NY Acad Sci 654:444-447

Horger BA, Taylor JR, Elsworth JD, Roth RH (1994): Preexposure to, but not cotreatment with, the neurotensin antagonist SR 48692 delays the development of cocaine sensitization. Neuropsychopharmacology 11:215-222

Jennes L, Stumpf WE, Kalivas PW (1982): Neurotensin: topographical distribution in rat brain by immunohistochemistry. J Comp Neurol 210:211-224

Kalivas PW, Burgess SK, Nemeroff CB, Prange AJ Jr (1983): Behavioral and neurochemical effects of neurotensin microinjection into the ventral tegmental area of the rat. Neuroscience 8:495-505

Kalivas PW, Miller JS (1984): Neurotensin neurons in the ventral tegmental area project to the medial nucleus accumbens. Brain Res 300:157-160

Kalivas PW, Taylor S (1985): Behavioral and neurochemical effect of daily injection with neurotensin into the ventral tegmental area. Brain Res 358:70-76

Kalivas PW, Weber B (1988): Amphetamine injection into the ventral mesencephalon sensitizes rats to peripheral amphetamine and cocaine. J Pharmacol Exp Ther 245: 1095-1102

Kalivas PW, Duffy P (1990): Effect of acute and daily neurotensin and enkephalin treatments on extracellular dopamine in the nucleus accumbens. J Neurosci 10:2940-2949 
Kalivas PW, Stewart J (1991): Dopamine transmission in the initiation and expression of drug- and stress-induced sensitization of motor activity. Brain Res Rev 16:223-244

Kantor L, Hewlett GHK, Gnegy ME (1999): Enhanced amphetamine- and $\mathrm{K}^{+}$-mediated dopamine release in rat striatum after repeated amphetamine: Differential requirements for $\mathrm{Ca}^{2+}$ - and calmodulin-dependent phosphorylation and synaptic vesicles. J Neurosci 19:3801-3808

Laitinen K, Crawley JN, Mefford IN, de Witte P (1990): Neurotensin and cholecystokinin microinjected into the ventral tegmental area modulate microdialysate concentrations of dopamine and metabolites in the posterior nucleus accumbens. Brain Res 523:342-346

Laruelle M (2000): The role of endogenous sensitization in the pathophysiology of schizophrenia: Implications from recent brain imaging studies. Brain Res Rev 31:371-384

Legault MA, Trudeau LE (2000): Differential action of neurotensin on intracellular calcium in dopaminergic neurons and astrocytes of the ventral mesencephalon. Society for Neuroscience Abstracts 26:1150

Lieberman JA, Sheitman BB, Kinon BJ (1997): Neurochemical sensitization in the pathology of schizophrenia: deficits and dysfunction in neuronal regulation and plasticity. Neuropsychopharmacology 17:205-229

Mazella J, Botto J-M, Guillemare E, Coppola T, Sarret P, Vincent J-P (1996): Structure, functionnal expression, and cerebral localization of the levocabastine-sensitive neurotensin/neuromedin $\mathrm{N}$ receptor from mouse brain. J Neurosci 16:5613-5620

Mazella J, Zsürger N, Navarro V, Chabry J, Kaghad M, Caput D, Ferrara P, Vita N, Gully D, Maffrand J-P, Vincent J-P (1998): The $100-\mathrm{kDa}$ neurotensin receptor is gp95/sortilin, a non-G-protein-coupled receptor. J Biol Chem 273:26273-26276

Nicot A, Rostène W, Bérod A (1994): Neurotensin receptor expression in the rat forebrain: a combined analysis by in situ hybridization and receptor autoradiography. J Comp Neurol 341:407-419

Piazza PV, Deminière J-M, Le Moal M, Simon H (1989): Factors that predict individual vulnerability to amphetamine self-administration. Science 245:1511-1513

Pierce RC, Kalivas PW (1997a): A circuitry model of the expression of behavioral sensitization to amphetaminelike psychostimulants. Brain Res Rev 25:192-216

Pierce RC, Kalivas PW (1997b): Repeated cocaine modifies the mechanism by which amphetamine releases dopamine. J Neurosci 17:3254-3261

Pierce RC, Quick EA, Reeder DC, Morgan ZR, Kalivas PW (1998): Calcium-mediated second messengers modulate the expression of behavioral sensitization to cocaine. J Pharmacol Exp Ther 286:1171-1176

Poncelet M, Souilhac J, Gueudet C, Terranova JP, Gully D, Le Fur G, Soubrié P (1994): Effects of SR 48692, a selective non-peptide neurotensin receptor antagonist, on two dopamine-dependent behavioural responses in mice and rats. Psychopharmacol 116:237-241

Robinson TE, Becker JB (1986): Enduring changes in brain and behavior produced by chronic amphetamine administration: a review and evaluation of animals models of amphetamine psychosis. Brain Res Rev 11:157-198

Robinson TE, Berridge KC (1993): The neural basis of drug craving: an incentive sensitization theory of addiction. Brain Res Rev 18:247-291

Robledo P, Maldonado R, Koob GF (1993): Neurotensin injected into the nucleus accumbens blocks the psychostimulant effects of cocaine but does not attenuate cocaine self-stimulation in the rat. Brain Res 622:105-112

Rompré P-P (1997): Repeated activation of neurotensin receptors sensitizes to the stimulant effect of amphetamine. Eur J Pharmacol 328:131-134

Rompré P-P, Perron S (2000): Evidence for a role of endogenous neurotensin in the initiation of amphetamine sensitization. Neuropharmacol 39:1880-1892

Santucci V, Gueudet C, Steinberg R, Le Fur G, Soubrié P (1997): Involvement of cortical neurotensin in the regulation of rat meso-cortico-limbic dopamine neurons: evidence from changes in the number of spontaneously active A10 cells after neurotensin receptor blockade. Synapse 26:370-380

Seroogy KB, Mehta A, Fallon JH (1987): Neurotensin and cholecystokinin coexistence within neurons of the ventral mesencephalon: projections to forebrain. Exp Brain Res 68:277-289

Sotty F, Soulière F, Brun P, Chouvet G, Steinberg R, Soubrié P, Renaud B, Suaud-Chagny M-F (1998): Differential effects of neurotensin on dopamine release in the caudal and rostral nucleus accumbens: a combined in vivo electrochemical and electrophysiological study. Neuroscience 85:1173-1182

Steinberg R, Brun P, Fournier M, Souilhac J, Rodier D, Mons G, Terranova JP, Le Fur G, Soubrié P (1994): SR 48692, a nonpeptide neurotensin receptor antagonist differentially affects neurotensin-induced behaviour and changes in dopaminergic transmission. Neuroscience 59:921-929

Steinberg R, Rodier D, Mons G, Gully D, Le Fur G, Soubrié P (1995): SR 48692-sensitive neurotensin receptors modulate acetylcholine release in the rat striatum. Neuropeptides 29:27-31

Studler JM, Kitabgi P, Tramu G, Hervé D, Glowinski J, Tassin JP (1988): Extensive co-localization of neurotensin with dopamine in rat meso-cortico-frontal dopaminergic neurons. Neuropeptides 11:95-100

Tanaka K, Masu M, Nakanishi S (1990): Structure and functional expression of the cloned rat neurotensin receptor. Neuron 4:847-854

Vezina P, Stewart J (1990): Amphetamine administered to the ventral tegmental area but not to the nucleus accumbens sensitizes rats to systemic morphine: lack of conditioned effects. Brain Res 516:99-106

Vezina P (1993): Amphetamine injected into the ventral tegmental area sensitizes the nucleus accumbens dopaminergic response to systemic amphetamine: an in vivo microdialysis study in the rat. Brain Res 605:332-337

Vezina P (1996): D1 dopamine receptor activation is necessary for the induction of sensitization by amphetamine in the ventral tegmental area. J Neurosci 16:2411-2420

Vincent JP (1995): Neurotensin receptors: Binding properties, transduction pathways, and structure. Cell Mol Neurobiol 15:501-512

Vincent JP, Mazella J, Kitabgi P (1999): Neurotensin and neurotensin receptors. Trends Pharmacol Sci 20:302-309

Vita N, Laurent P, Lefort S, Chalon P, Dumont X, Kaghad M, Gully D, Le Fur G, Ferrara P, Caput D (1993): Cloning and 
expression of a complementary DNA encoding a high affinity human neurotensin receptor. FEBS Lett 317:139-142

Warburton EC, Mitchell SN, Joseph MH (1996): Calcium dependence of sensitised dopamine release in rat nucleus accumbens following amphetamine challenge: implications for the disruption of latent inhibition. Behav Pharmacol 7:119-129

Wolf ME (1998): The role of excitatory amino acids in behavioral sensitization to psychomotor stimulants. Prog Neurobiol 54:679-720
Woulfe J, Beaudet A (1992): Neurotensin terminals form synapses primarily with neurons lacking detectable tyrosine hydroxylase immunoreactivity in the rat substantia nigra and ventral tegmental area. J Comp Neurol 321:163-176

Zahm DS, Heimer L (1988): Ventral striatopallidal parts of the basal ganglia in the rat: I. Neurochemical compartmentation as reflected by the distribution of neurotensin and substance $\mathrm{P}$ immunoreactivity. J Comp Neurol 272:516-535 